\title{
Prevalence and determinants of high risk human papilloma virus in Hyderabad, India
}

\section{Chandana V.*, Rasheeda Begum Gaguturu}

Department of Obstetrics and Gynecology, Mahavir Institute of Medical Sciences, Vikarabad, Telangana, India

Received: 30 December 2017

Accepted: 31 January 2018

\author{
*Correspondence: \\ Dr. Chandana V., \\ E-mail: irtnam.@yahoo.com
}

Copyright: (C) the author(s), publisher and licensee Medip Academy. This is an open-access article distributed under the terms of the Creative Commons Attribution Non-Commercial License, which permits unrestricted non-commercial use, distribution, and reproduction in any medium, provided the original work is properly cited.

\begin{abstract}
Background: Cervical cancer is the most common cancer among india women and age standardized mortality rate are the highest in south central Asia. In the past decade an among aetiologic association between infection with high risk human papilloma virus and development of cervical cancer has been increased. The study was aimed at studying the prevalence and determinants of high risk human papilloma virus in these patients.

Methods: This study was conducted for a period of one year to know the prevalence and determinants of high risk human papilloma virus in the patients attending gynaec out patient department. A total of 266 married women between 15-75 were randomly selected for the study.

Results: There is high prevalence of HPV in low (43.3\%)/mid (37.4\%) socio economic class (17.6\%). But the result was not statistically significant $(\mathrm{p}=0.149)$. higher prevalence of HPV was found in multiparas $(39.4 \%)$ compared to multiparas $(33.3 \%)$ which was not statistically significant $(\mathrm{p}=0.233)$. Husbands of 252 women were circumcised out of which 96 wives were positive for HPV DNA (38.1\%). Among 14 women with no history of circumcision in their husband HPV DNA positive (28.6\%). Correlation of cytology with HPV DNA among different age groups showed increasing prevalence with age but the result was not statistically significant $(\mathrm{p}=0.115)$. the result showed that age at marriage, higher the prevalence of HPV DNA. The result was statistically significant $(\mathrm{p}=0.017)$. with increasing state of education, the prevalence of HPV infection decreased, but the result was not statically significant $(\mathrm{p}=0.142) .51 .3 \%$ of women of who were not education were positive for HPV as against only $25 \%$ of graduates were HPV positive. Conclusions: Genital hygiene, genetic polymorphisms and other environmental cofactors among HPV DNA positive women, which prevent oncogenesis.
\end{abstract}

Keywords: Bethesda system, Cervical cancer, Human papilloma virus

\section{INTRODUCTION}

Cervical cancer is the second most common cause of cancer in women worldwide. The estimated number of new cases per yr 4,93,100 and leading to approximately $2,73,000$ deaths, of which $70 \%$ occur in developing countries.

Cervical cancer is the most common cancer among india women. Approximately 20,000 new cases were detected in the yr 2000. India's cervical cancer age standardized incidence rate $(30.7$ per 100,000$)$ and age standardized mortality rate $(17.4$ per 100,000$)$ are the highest in south central Asia. In the past decade a among aetiologic association between infection with high risk human papilloma virus and development of cervical cancer has been established. ${ }^{1,2}$

The prevalence of high risk HPV in specimen of invasive cervical cancer is greater than $90 \%$ in world wide samples tested by PCR (IARC) publications or equivalent technology. When corrections are made for non- 
representative tissue and inadequate DNA it was shown that $99 \%$ percent of all carcinomas harbor high risk HPV risk HPV is present in $50 \%$ of ASCUS specimens, $80 \%$ of 1sril, $90 \%$ to $95 \%$ of HSIL.

HPV is widely prevalent sexually transmitted virus. although the majority of infections are benign and transient, persistent infection is associated with the development of carcinoma cervix.

Owing to the strong association, it has been suggested that high risk HPV detection might be used as a tool to identify women at risk for the subsequent development of carcinoma cervix. Middle eastern and predominantly Muslim and Buddhist countries tended to have the lowest rates, while Latin American and predominantly Christian and Hindu countries generally had the highest rates.

Muslim women and jewish women are in general marked to have low prevalence carcinoma cervix and thus HPV infection (WHO data bank cervix uteri reports 19771997). ${ }^{3}$ There is ample data on prevalence of HPV in women cervical cancer, however data on HPV prevalence in general population of various geographical regions and communities from India is scarce.

The present study addresses this issue. Studies examining risk factors for HPV infection not been entirely consistent, probably due to difference in the studied population and the detection methods. The point prevalence observed are country dependent and are strongly related to the dominant sexual behaviour patterns. Some of the identified determinants of HPV infection are age of woman at sexual initiation, the life time number of partners of woman and male sexual partners, and frequency of sexual contacts between men and prostitutes.

Possible determinants of HPV Prevalence include age of men at sexual initiation, the age difference within couples at first marriage and prevalence of male circumcision. Present study is to determine the prevalence and determinants of high risk-human papilloma virus infection in woman attending gynaecological outpatient department at Muslim maternity hospital.

\section{METHODS}

The present study was conducted at Muslim hospital. Muslim maternity hospital is a 200 bedded tertiary hospital with about 40-50 woman attending gynecology OPD for various complaints. These patients are predominantly Muslim woman details like socio economic status with specific social, cultural and sexual behaviour like early age at marriage, high parity, male circumcision was noted.

A total of 266 woman were enrolled for the study. A structured questionnaire designed especially for this study was administered by the gynecologist. The questionnaire included information on sociodemographic characteristics (age, educational level, marital status, occupation, country of birth), sexual practices (age of first sexual intercourse, number of lifetime sexual partners), reproductive health (number and dates of pregnancies, children, TOPs (voluntary termination of pregnancy), use of contraceptives methods), general health (smoking habits, weight and height, history of major illness), gynaecological history (previous cervical smears and results, past history of STI).

Smokers were classified according to having ever smoked or not and whether they had smoked in the last year. HIV, hepatitis B virus (HBV), hepatitis C virus (HCV) and syphilis serology were also recorded. The outcome variables were HR-HPV infection and SIL. All women had a cervical specimen taken for Papanicolaou cytology and HPV testing.

Smears were read blinded to all study variables in the reference Pathology service. HR-HPV infection was determined through the HPV DNA test Hybrid Capture II using the oncogenic or probe B cocktail (HPV types 16, $18,31,33,35,39,45,51,52,56,58,59$, and 68), in accordance with the manufacturer's instructions.

The samples with a relative light unit/cut-off ratio $>1.0$ were considered positive for one or more HPV genotypes included in the probe B cocktail and the specimens with a relative light unit/cut-off ratio of between 1.0 and 2.5 were retested to confirm positive results.

Cervical smears were performed with an Ayre's wooden spatula and an endocervical brush. Samples were fixed with Labofix and classified according to Bethesda 2001.

The statistical analysis was done using SPSS version.

\section{RESULTS}

Overall the oncogenic HPV $(16,18,31,35,51,52 b, 45)$ was found in $90(37.6 \%)$ of the study subjects. The age group of the woman ranged from 17 to $75 \mathrm{yr}$, the man age was 35.77. The age distribution of the study population is given in the following table majority of the subjects belong to age group 30-40 $\mathrm{yr}$.

Most common effected group is 30-40 years married women of middle socio economic class with primary or secondary level of education. Most of the woman were married below the age of $20 \mathrm{yr}$ and were multiparas.

All most all the woman -252 were Muslim with history of circumcision in their partner. Only 14 patients were Hindus with no history of circumcision.

None of the study subjects had given the history of exposure or smoking husbands of 51 woman were smokers and hence these women exposed to passive smoking. 
Table 1: Demographic distribution of the subjects.

\begin{tabular}{|c|c|c|}
\hline & Frequency $(n=266)$ & Percent \\
\hline \multicolumn{3}{|c|}{ Age group (in years) } \\
\hline$<30$ & 84 & 31.6 \\
\hline $30-40$ & 113 & 42.5 \\
\hline $40-50$ & 44 & 16.5 \\
\hline$>50$ & 25 & 9.4 \\
\hline \multicolumn{3}{|l|}{ Marital status } \\
\hline Married & 250 & 94.0 \\
\hline Widowed & 5 & 1.9 \\
\hline Divorce & 11 & 4.1 \\
\hline \multicolumn{3}{|c|}{ Socio economic status } \\
\hline Low & 67 & 25.2 \\
\hline Middle & 182 & 68.4 \\
\hline High & 17 & 6.4 \\
\hline \multicolumn{3}{|l|}{ Education } \\
\hline None & 39 & 14.7 \\
\hline Primary & 66 & 24.8 \\
\hline Secondary & 112 & 42.1 \\
\hline Graduate & 36 & 13.5 \\
\hline Post graduate & 13 & 4.9 \\
\hline \multicolumn{3}{|c|}{ Age at marriage or first intercourse } \\
\hline$<16$ & 42 & 15.8 \\
\hline $16-20$ & 160 & 60.2 \\
\hline $20-24$ & 51 & 19.2 \\
\hline$>25$ & 13 & 4.9 \\
\hline Total & 266 & 100 \\
\hline \multicolumn{3}{|l|}{ Parity } \\
\hline Nullipara & 16 & 6.0 \\
\hline Primipara & 24 & 9.0 \\
\hline Multipara & 226 & 85.0 \\
\hline Total & 266 & 100 \\
\hline
\end{tabular}

Most of the subjects never used contraception. 35 woman used oral contraceptive pills at sometime, 20 women used IUCD, 15 women gave history of usage of condom by their husbands.

The chief complaints with which the study population attended were white discharge $(32.95 \%)$, menstrual disturbances (15.64\%), and pain abdomen (18.35\%).

Genital warts were not documented on clinical examination in any subject. Of the 267 pap smears taken, reporting done by the Bethesda system. Showed 253 smears negative for intraepithelial lesion (17-normal 236specific or no specific inflammation) 1-ASUS, 7 reported as low grade squamous intra epithelial lesion, 2 as high grade squamous intra epithelial lesion, and 3 as squamous cell carcinoma.

The high reporting of inflammatory smears was because $32.95 \%$ of woman had chief complaint of white discharge.

Prevalence of HPV DNA among different age group showed increasing prevalence with age but the result was not statistically significant $(\mathrm{p}=0.115)$ Married, divorced or widowed had no difference in the HPV prevalence $(\mathrm{p}=0.99)$ education status of women-HPV. With increasing state, the prevalence of HPV infection decreased, but the result was not statistically significant $(\mathrm{P}=0.142)$.

Table 2: Prevalence of variables among the study subjects.

\begin{tabular}{|c|c|c|}
\hline Circumcision & Frequency & Percent \\
\hline Yes & 252 & 94.7 \\
\hline No & 14 & 5.3 \\
\hline \multicolumn{3}{|c|}{ Passive smoking } \\
\hline Yes & 51 & 19.2 \\
\hline No & 215 & 80.8 \\
\hline \multicolumn{3}{|l|}{ Contraception } \\
\hline None & 196 & 73.7 \\
\hline $\mathrm{OCP}$ & 35 & 13.2 \\
\hline IUCD & 20 & 7.5 \\
\hline Condom & 15 & 5.6 \\
\hline \multicolumn{3}{|l|}{ STD } \\
\hline Yes & 75 & 28.2 \\
\hline No & 191 & 71.8 \\
\hline \multicolumn{3}{|l|}{ HPV DNA } \\
\hline Positive & 100 & 37.6 \\
\hline Negative & 166 & 62.4 \\
\hline Total & 266 & 100.0 \\
\hline \multicolumn{3}{|l|}{ Papmear } \\
\hline Normal & 17 & 6.4 \\
\hline Inflammatory & 236 & 88.7 \\
\hline ASCUS & 1 & 0.4 \\
\hline LSIL & 7 & 2.6 \\
\hline HSIL & 2 & 0.8 \\
\hline Cacervix & 3 & 1.1 \\
\hline Total & 266 & 100.0 \\
\hline
\end{tabular}

$51.3 \%$ of women who were not educated were positive for HPV as against only $25 \%$ of graduates or post graduates were HPV positive.

Results showed high prevalence of HPV in low (43.3\%) mid $(37.4 \%)$ socio economic class compared to high class $(17.6 \%)$. But the result was not statistically significant $(\mathrm{p}=0.149)$.

The result showed at the younger the age at marriage, higher the prevalence of HPV DNA. Woman who had intercourse before $20 \mathrm{yr}$ of age had high prevalence of HPV infection. $50 \%$ prevalence observed in $>28$ yr age at marriage group was because only two women were in that group. The result was statistically significant $(\mathrm{p}=0.017)$.

Correlation of cytology with HPV DNA showed that $100 \%$ positivity in HSIL and squamous cell carcinoma. Only one case of ASCUS was reported which was HPV DNA positive reported as normal had $11.8 \%$ HIV DNA positive. $37.3 \%$ are smears with inflammation and $57.1 \%$ of lsil were HPV DNA was positive. 
Table 3: Prevalence of HPV DNA among the papsmears in demographic variables.

\begin{tabular}{|c|c|c|c|c|c|}
\hline \multicolumn{3}{|l|}{ Variable } & \multicolumn{2}{|c|}{ HPV DNA } & \multirow{2}{*}{$\begin{array}{l}\text { Total } \\
250\end{array}$} \\
\hline \multirow{6}{*}{ Marital status } & \multirow{2}{*}{ Married } & Count & 94 & 156 & \\
\hline & & $\%$ within marital status & 37.6 & $62.4 \%$ & 100 \\
\hline & \multirow{3}{*}{ Divorced } & Count & 2 & 3 & 5 \\
\hline & & \%within marital status & 40 & $60.0 \%$ & 100 \\
\hline & & Count & 4 & 7 & 11 \\
\hline & widowed & $\%$ within marital status & $36.4 \%$ & $63.6 \%$ & 100 \\
\hline \multirow{10}{*}{ Education } & \multirow{2}{*}{ None } & Count & 20 & 19 & 39 \\
\hline & & \%within education & $51.3 \%$ & $48.7 \%$ & 100 \\
\hline & Primary & Count & 24 & 42 & 66 \\
\hline & & \%within education & $36.4 \%$ & $63.6 \%$ & 100 \\
\hline & \multirow{2}{*}{ Secondary } & Count & 44 & 68 & 112 \\
\hline & & $\%$ within education & $39.3 \%$ & $60.7 \%$ & 100 \\
\hline & \multirow{2}{*}{ Graduate } & Count & 9 & 27 & 36 \\
\hline & & $\%$ within education & $25.0 \%$ & $75.0 \%$ & 100 \\
\hline & \multirow{2}{*}{ Post graduate } & Count & 3 & 10 & 13 \\
\hline & & \%within education & $23.1 \%$ & $76.9 \%$ & 100 \\
\hline \multirow{6}{*}{$\begin{array}{l}\text { Socioeconomic } \\
\text { Status }\end{array}$} & \multirow{2}{*}{ Low } & Count & 29 & 38 & 67 \\
\hline & & $\%$ within class & $43.3 \%$ & $56.7 \%$ & 100 \\
\hline & \multirow{2}{*}{ Middle } & Count & 68 & 114 & 182 \\
\hline & & $\%$ within class & $37.4 \%$ & 62.6 & 100 \\
\hline & \multirow{2}{*}{ High } & Count & 3 & 14 & 17 \\
\hline & & $\%$ within class & $17.6 \%$ & $82.4 \%$ & 100 \\
\hline \multirow{8}{*}{ Age at marriages } & \multirow{2}{*}{$<16$} & Count & 21 & 21 & 42 \\
\hline & & $\%$ within age $\mathrm{m}$-gr & 50 & 50 & 100 \\
\hline & \multirow{2}{*}{$16-20$} & Count & 65 & 95 & 160 \\
\hline & & Within age $\mathrm{m}$-gr & 40.6 & 59.4 & 100 \\
\hline & \multirow{2}{*}{$20-24$} & Count & 11 & 40 & 51 \\
\hline & & Within age $\mathrm{m}$-gr & 21.6 & 78.4 & 100 \\
\hline & \multirow{2}{*}{$>25$} & Count & 3 & 10 & 13 \\
\hline & & $\%$ within age $\mathrm{m}$-gr & 23.6 & 76.9 & 100 \\
\hline
\end{tabular}

There is higher prevalence of HPV was found of HPV was found on multiparas $39.4 \%$ compared to nulliparas $(18.8 \%)$ and primiparas $(33.3 \%)$. The result was not statistically significant $(\mathrm{p}=0.233)$ few women used condom and HPV prevalence was less in them compared to OCP/IUCD user's. the result was not statistically significant. Passive smoking had no effect on HPV prevalence. Husbands of 252 women were circumcised out of which 96 wives were positive for HPV DNA $(38.1 \%)$ among 14 women with no history of circumcision in their husbands four were HPV DNA positive $(28.6 \%)$ chi-square tests: $\mathrm{p}=0.474$.

\section{DISCUSSION}

Incidence of cervical cancer varies by region of the world, ranging from 4.8 per 100,000 in western aia (i.e., $3.27 / 100,000$ in Israel) to 44.3 in eastern Africa (i.e., $61.08 / 100,000$ in Iraq and 5.76/100,000 in Swaziland). Middle eastern and predominantly Muslim and Buddhist country tended to have the lowest rates, while latin American and predominantly Christiana and Hindu countries generally had the highest rates. ${ }^{4,5}$
Muslim women and Jewish women are in general marked to have low prevalence carcinoma cervix and thus HPV infection. ${ }^{6}$ There is ample data on prevalence of HPV prevalence in general population of various geographical regions and communities from india is scarce. The present study addresses this issue.

The prevalence of oncogenic HPV 16,18,31,32,51,52b,45 among the women in the index study was $37.6 \%$. the study group had $94.7 \%$ of Muslim population with circumcision in male partners. The prevalence of HPV in these women was $38.1 \%$. The high prevalence could be due to the selection of subjects who were symptomatic (32.95\% came with complaint of white discharge) being a hospital-based study and the HPV types included were $16,18,31,33,51,52 \mathrm{~b}$ and 45 while in most of the studies only HPV 16 and 18 were studied.

In spite of the prevalence of high risk HPV there were only $1.9 \%$ of cases with moderate to severe dysplasia and carcinoma cervix. Similar results were reported from study in Muslim population by Al-muammer et al in Riyadh Arabia, where in spite of high prevalence of HPV 
16/18 (31.6\%) follow up had shown low rate of progression to $\mathrm{CIN}^{7}$ Male circumcision has been given credibility for providing protective shelter to the female partners by getting lesser HPV infection and thus reducing the risk for $\mathrm{Ca} \mathrm{cx}$. This hypothesis however has been counter argued by others.

Table 4: Prevalence of HPV DNA among the papmears.

\begin{tabular}{|c|c|c|c|c|c|}
\hline \multicolumn{3}{|l|}{ Variable } & \multicolumn{2}{|c|}{ HPV DNA } & \multirow{2}{*}{$\begin{array}{l}\text { Total } \\
17\end{array}$} \\
\hline \multirow{12}{*}{ Papsmear } & \multirow{2}{*}{ Normal } & Count & Positive & Negative & \\
\hline & & $\%$ withih papasmear & 2 & 15 & $100 \%$ \\
\hline & \multirow{2}{*}{ Inflammatory } & Count & $11.8 \%$ & $88.2 \%$ & 236 \\
\hline & & $\%$ within papsmear & 88 & 148 & 100 \\
\hline & \multirow{2}{*}{ Ascus } & Count & $37.3 \%$ & $62.7 \%$ & 1 \\
\hline & & $\%$ within papsmear & 1 & 0 & 100 \\
\hline & \multirow{2}{*}{ LSIL } & Count & 100 & 0 & 7 \\
\hline & & $\%$ within papsear & 4 & 3 & 100 \\
\hline & \multirow{2}{*}{ HSIL } & Count & 57.1 & 42.9 & 2 \\
\hline & & \%within papsmear & 2 & 0 & 100 \\
\hline & \multirow{2}{*}{ Ca cervix } & Total & 100 & 0 & 3 \\
\hline & & \%within papsmear & 3 & 0 & 100 \\
\hline \multirow{6}{*}{ Parity } & \multirow{2}{*}{ nulllipara } & Count & 3 & 13 & 16 \\
\hline & & $\%$ within parity & 18.8 & 81.3 & 100 \\
\hline & \multirow[t]{2}{*}{ Primaipora } & Count & 8 & 16 & 24 \\
\hline & & $\%$ within parity & 33.3 & 66.7 & 100 \\
\hline & \multirow{2}{*}{ multipara } & Count & 89 & 137 & 226 \\
\hline & & $\%$ within parity & 39.4 & $60.6 \%$ & 100 \\
\hline \multirow{4}{*}{ Smoking } & \multirow{2}{*}{ Yes } & Count & 19 & 32 & 51 \\
\hline & & $\%$ with smoking & $37.3 \%$ & $62.7 \%$ & 100 \\
\hline & \multirow{2}{*}{ No } & Count & 81 & 134 & 215 \\
\hline & & $\%$ within smoking & 37.7 & $62.3 \%$ & 100 \\
\hline \multirow{4}{*}{ STD } & \multirow{2}{*}{ Yes } & Count & 27 & 48 & 75 \\
\hline & & $\%$ within std h/o & 36 & 64 & 100 \\
\hline & \multirow{2}{*}{ No } & Count & 73 & 118 & 191 \\
\hline & & $\%$ within std h/o & $38.2 \%$ & $61.8 \%$ & 100 \\
\hline \multirow{8}{*}{ Contraception } & \multirow{2}{*}{ None } & Count & 74 & 122 & 196 \\
\hline & & $\%$ within contraception & $37.8 \%$ & $62.2 \%$ & 100 \\
\hline & \multirow{2}{*}{$\mathrm{OCP}$} & Count & 14 & 21 & 35 \\
\hline & & $\%$ within contraception & $40.0 \%$ & $60.0 \%$ & 100 \\
\hline & \multirow{2}{*}{ ICDU } & Count & 7 & 13 & 20 \\
\hline & & $\%$ within contraception & $35.0 \%$ & $65.0 \%$ & 100 \\
\hline & \multirow[t]{2}{*}{ Condom } & Count & 5 & 10 & 15 \\
\hline & & \%within contraception & $33.3 \%$ & $66.7 \%$ & 100 \\
\hline \multirow{4}{*}{ Circumcision } & \multirow[t]{2}{*}{ yes } & count & 96 & 156 & 252 \\
\hline & & $\%$ within circumcision & $38.1 \%$ & $61.9 \%$ & $100 \%$ \\
\hline & & Count & 4 & 10 & 14 \\
\hline & no & $\%$ within circumcision & $28.6 \%$ & $71.4 \%$ & $100 \%$ \\
\hline
\end{tabular}

Whether circumcision has any protective role in preventing the carcinogenesis remains to be proven. According to Das et al both prevalence of ca cx and HPV infection among Muslim women from Jammu and Kashmir are the lowest in india. statements are also made that the rate of ca cx and HPV among India Muslim women is strikingly low as revealed from the India cancer registries. ${ }^{8-10}$ Of interest in studies conducted in India and Pakistan, premarital sex is uncommon in the various religious groups in these and surrounding countries, where in general Muslims are circumcised and Hindus are not. In a study of 5000 cervical and 300 penile cancer cases in madras between 1982 and 1990 the incidence was low amongst Muslim women. When compared with and Christian and was not seen at all in Muslims men. In a case control study of 1107 Indian woman with cervical cancer, sex with uncircumcised men or those circumcised after the age of $1 \mathrm{yr}$ was reported in 
1993 to be associated with a 4-flod higher risk of cervical cancer. This figure was, moreover, obtained after controlling for factors such as age of intercourse, and education. Another study published various types of cancer in the valley of Kashmir concluded that universal male circumcision in the majority community was responsible for the low rate of cervical cancer compared with the rest of India. ${ }^{11}$

Promiscuity is a significant factor that has been known to be associated with HPV infection. Worldwide studies have reported higher number of lifetime sexual partners as a risk factor for HPV infection. In our study none of the women admitted promiscuity, very few reported promiscuities in their husbands. The sociocultural stigma of our society plays a role in the under reporting of this sensitive parameter.

In present study prevalence of HPV was less in nulliparas $(18.8 \%)$ and primiparas $(33.3 \%)$ but the difference was not statistically significant. Dattagupta et al, Arora et al, Locanzo et al too did not observe any significant association of HPV $16 / 18$ with parity. ${ }^{12-14}$ A history of STD has been identified as a risk factor for HPV infection. In this group of low-risk women, we did not detect any association between self-reported STD history and incidence of HPV.

The present report is few of its kind in the Indian context, where detection of HPV on Muslim women has been done. This kind of data not only reflects on the effect of socio-cultural behaviour between the religious groups on the prevalence and natural history of HPV, it can also be utilized in the prevention/control of ca cx in India. The study results reflect the need for further studies in understanding what lies between the causal exposure and the disease and point, and to focus on the exploration of additional associations with putative environmental cofactors, religions practices, sexual behaviour, makers of viral and host interactions among HPV-DNA positive women leading to progression to precancer.

\section{CONCLUSION}

Study generates epidemiological data prevalence of high risk HPV in the Muslim women visiSting the study has shown that in spite of the high prevalence of the oncogenic HPV in the study group, constituted chiefly of muslim population, the incidence of CIN2, CIN3 AS detected by colposcopy and guided biopsies where ever needed was less, reflecting the presence of factors preventing the oncogenesis in this set of population. The prevalence increased with early marriages, high parity, low socio-economic status of education.

Although good success has obtained in phase 3 clinical trials with vaccines against HPV 16 and 18 phases 2 trials on two other high-risk are in progress, it should be noted that there are 200 types of HPV, 50 of which have been described in the ano-genital region. Ideally vaccination against the most common types (HPV 16-18) could prevent two-thirds of cervical cancers. Elimination of these from the population might take 20-30 yr. This falls short of $100 \%$ protection. However, and the fear is that at the population level HPV types that are currently rarer will take over and replace the types vaccinated against.

Study emphasizes the aspect of primary prevention by good education, modification of sexual behaviour, practice of good genital hygiene. The study results reflect the need for further studies in understanding what lies between the causal exposure and the disease end point, and to focus on the aspects of circumcision. Genital hygiene, genetic polymorphisms and other environmental cofactors among HPV DNA positive women, which prevent oncogenesis.

Funding: No funding sources

Conflict of interest: None declared

Ethical approval: The study was approved by the Institutional Ethics Committee

\section{REFERENCES}

1. Ferlay J, Soerjomataram I, Ervik M, Dikshit R, Eser S, Mathers C, et al. GLOBOCAN 2012 v1.0, Cancer Incidence and Mortality Worldwide: IARC CancerBase No. 11. Lyon, France: International Agency for Research on Cancer; 2013. Available at http://www.globocan.iarc.fr. Accessed 2013 Dec 2016.

2. Franco EL, Duarte-Franco E, Ferenczy A. Cervical cancer: Epidemiology, prevention and the role of human papillomavirus infection. Can Med Assoc J. 2001;164:1017-25

3. WHO. Control of cancer of the cervix uteri. A WHO meeting. Bull World Health Organization. 1986;64:607-18.

4. Davies P, Kornegay J, Iftner T. Current methods of testing for human papillomavirus. Best Pract Res Clin Obstet Gynecol. 2001 Oct;15(5):677-700.

5. Rozendaal L, Westerga J, Van der Linden JC, Walboomers JM, Voorhorst FJ, Risse EK et al. PCR based high risk HPV testing is superior to neural network based screening for predicting incident CIN III in women with normal cytology and borderline changes. J Clin Patholol. 2000;53:606-11.

6. Kjaer S, Høgdall E, Frederiksen K, Munk C, van den Brule A, Svare E, et al. The absolute risk of cervical abnormalities in high-risk human papillomaviruspositive, cytologically normal women over a 10-year period. Cancer Res. 2006;66:10630-6.

7. Al-Muammar T, Al-Ahdal MN, Hassan A, Kessie G, Dela Cruz DM, Mohamed GE. Human papilloma virus-16/18 cervical infection among women attending a family medical clinic in Riyadh. Ann Saudi Med. 2007;27:1-5.

8. Turki R, Sait K, Anfinan N, Sohrab SS, Abuzenadah AM. Prevalence of human papillomavirus in women 
from Saudi Arabia. Asian Pac J Cancer Prev. 2013;14:3177-81.

9. Bondagji NS, Gazzaz FS, Sait K, Abdullah L. Prevalence of high-risk human papillomavirus infections in healthy Saudi women attending gynecologic clinics in the western region of Saudi Arabia. Ann Saudi Med. 2013;33:13-7.

10. Sait KH, Gazzaz FS. Molecular tests to detect human papillomavirus infection in patients with cervical dysplasia and invasive cervical cancer in Saudi Arabia. Pathol Lab Med Int. 2011;3:25-9.

11. Smith JS, Lindsay L, Hoots B, Keys J, Franceschi S, Winer R, Clifford GM. Human papillomavirus type distribution in invasive cervical cancer and highgrade cervical lesions: a meta-analysis update. Int $\mathrm{J}$ Cancer. 2007;121:621-32.

12. Duttagupta C, Sengupta S, Roy M, Sengupta D, Bhattacharya P, Laikangbam P, et al. Are Muslim women less susceptible to oncogenic human papillomavirus infection.A study from rural eastern India. Int J Gynecol Cancer. 2004;14:293-303.

13. Aggarwal R, Gupta S, Nijhawan R, Suri V, Kaur A, Bhasin V, Arora SK. Prevalence of high - risk human papillomavirus infections in women with benign cervical cytology: A hospital based study from North India. Indian J Cancer. 2006;43:110-6.

14. Lazcano-Ponce E, Herrero R, Munoz N, Cruz A, Shah KV, Alonso $\mathrm{P}$ et al. Epidemiology of HPV infection among Mexican women with normal cervical cytology. Int J Cancer. 2001;91:412-20.

Cite this article as: Chandana V, Gaguturu RB. Prevalence and determinants of high risk human papilloma virus in our local area. Int J Reprod Contracept Obstet Gynecol 2018;7:1012-8. 